\title{
Quality Improvement and Implementation Science
}

Editors

MEGHAN B. LANE-FALL

LEE A. FLEISHER

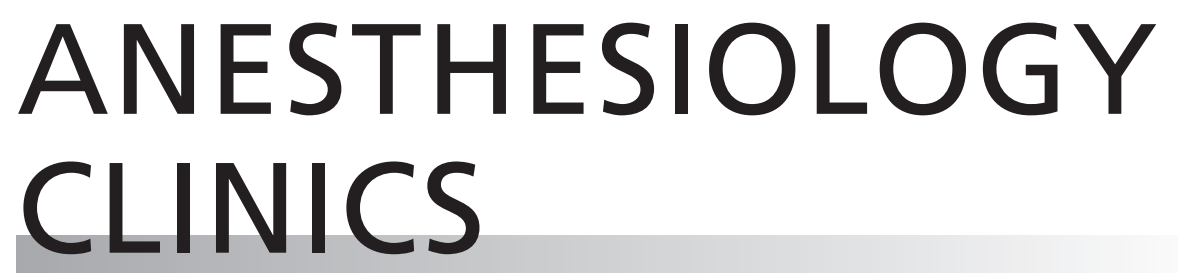

www.anesthesiology.theclinics.com

Consulting Editor

LEE A. FLEISHER

March 2018 • Volume 36 - Number 1 